Николчо СП $А С О В$

\title{
ЕВРОПСКАТА УНИЈА И БЕГАЛСКО-МИГРАНТСКАТА КРИЗА: ОДГОВОР И ПРЕДИЗВИЦИ
}

\section{Кратка содржина}

Речиси 25 години по падот на Берлинскиот sид, денес Европа повторно се соочува со иничирање бариери и затворање граници, пред сѐ како резултат на бранот бегалии и мигранти од Блискиот Исток, Африка и Азија. Во тој контекст, несомнено е дека во наредниот период ЕУ ќе биде соочена со предизвикот за сочијализација и интеграција на големиот број мигранти и бегалџи кои се веке на нејзина територија, а паралелно со тоа и со предизвикот за спречување нови миграции на нејзина територија. Трудот ги анализира карактеристиките на бегалско-мигрантската криза, како и инструментите кои ЕУ ги применува за справување со неа. За таа цеел, предмет на анализа посебно претставуваат: терминолошкото определување на кризата, меѓународната заштита на бегалците $и$ мигрантите, пристапот на ЕУ во справувањето со кризата, особено низ призмата на договорот ЕУ - Туриија, како и предизвичите за ЕУ во периодот ито следува.

Клучни зборови: ЕУ, БЕГАЛЦИ, МИГРАНТИ, КРИЗА

\section{Бегалска или мигрантска криза?}

Од меѓународен нормативен аспект, бегалците се лица кои поради страв од прогон базиран на религиозни, национални и политички причини се наоѓaат надвор од земјата чие државјанство го имаат и тие немаат заштита од таа земја, како и лица кои немаат државјанство кога од наведените причини се наоѓаат надвор од земјата на нивното претходно место на живеење и од страв не смеат да се вратат во таа земја. ${ }^{1}$ Исто така, статусот бегалец го имаат и лицата кои ги напуштаат матичните земји поради опасност од насилство, вооружени судири или други околности со кои сериозно е нарушен јавниот ред и мир. Од друга страна, со статусот бегалец не може да се стекне лице за кое постои основано сомнение дека:

- извршило злосторство против мирот, воено злостроство или злосторство против човештвото;

- извршило тешко кривично дело надвор од земјата која го прифатила пред да биде примено на нејзина територија како бегалец; и

\footnotetext{
${ }^{1}$ Член 1, Конвенција за статусот на бегалците, ООН, 1951 година. Извор: http://www.unhcr. org/about-us/background/4ec262df9/1951-convention-relating-status-refugees-its-1967-protocol. $\mathrm{html}$
} 
- ако е виновно за постапка која е спротивна на целите и принципите од Повелбата на $\mathrm{OH}^{2}$

Тргнувајќи од перцепцијата дека бегалците претставуваат една од најранливите групи луѓe, Конвенцијата за статусот на бегалците (1951) и Протоколот (1967) имаат цел да обезбедат нивна адекватна заштита. Оттука, тие јасно ги дефинираат правата на бегалците, но и обврските на 148 држави-потписнички на Конвенцијата.

Според Конвенцијата, неопходно е сите бегалци да се третираат без дискриминација во поглед на верата и земјата на потекло. ${ }^{3}$ Бегалците кои законски престојуваат во некоја држава имаат право да го изберат местото на својот престој и слободно да се движат под услови предвидени со прописите кои под исти околности важат за странците, воопшто. ${ }^{4}$ Притоа, државата домаќин е должна да им издаде на бегалците документи за идентификација доколку тие не поседуваат валидни патни исправи. ${ }^{5}$ Во таа насока, Конвенцијата, исто така, забранува преземање казнени мерки против бегалци кои илегално влегуваат или престојуваат во држава, под услов тие веднаш да се пријават на властите и да изнесат оправдани причини за нивното бесправно влегување или престој во земјата. ${ }^{6}$ Државите не смеат да ги протеруваат бегалците во други земји каде што им е загрозен животот или слободата поради нивната веросиповед, националност или политичко убедување.

Од друга страна, правото на слободно движење на луѓето, меѓу другото, е загарантирано и со меѓународното право за човековите права. Имено, слободата на движење подразбира право на поединецот за напуштање на која било држава, вклучувајќи ја и сопствената (без оглед на карактерот на напуштањето, привремен или траен), како и право на поединецот за враќње во сопствената држава. ${ }^{7}$ Постои широк спектар на причини кои предизвикуваат миграциски движења на луѓето (емиграција или имиграција). Најчесто, економските миграции претставуват доминантен облик на доброволни миграции, додека воените дејства и нивните последици претставуваат најчести фактори за присилните миграции. Без оглед на причините за појава на миграциите, според Универзалната декларација за човековите права на ООН (1948), секој има право да бара и да ужива азил од прогони во друга држава. Сепак, ова право не се однесува во случај на прогон, што подразбира кривични дела од неполитичка природа или на постапки спротивни на целите и начелата на $\mathrm{OOH}^{8}$

\footnotetext{
${ }^{2}$ Ibid.

${ }^{3}$ Ibid,чл. 3

${ }^{4}$ Ibid,чл. 26

5 Ibid,чл. 27

${ }^{6}$ Ibid,чл. 31

7 Чл. 13, Универзална декларација за човековите права, ООН, 1948. Извор: http://www. ohchr.org/ EN/UDHR/Documents/UDHR_Translations/eng.pdf

${ }^{8}$ Ibid., чЛ. 14
} 
Споредено со мигрантите, бегалците не ја уживаат заштитата на сопствената држава и како резултат на страв од прогон, национална, религиозна или политичка припадност, се принудени на нејзино напуштање. Согласно со меѓународните правни норми, признавањето на статусот бегалец нужно иницира и негова соодветна заштита која е неопходна, бидејќи нивното враќае во матичните држави може да претставува сериозен безбедносен предизвик за нив. Всушност, нивната состојба често е толку опасна и неподнослива што преминувањето на државната граница претставува единствен излез и решение за спас на сопствениот живот. Токму меѓународната заштита, која произлегува од статусот бегалец, во одредени ситуации претставува доминантна причина за злоупотреби на овој статус. Имено, разни категории луѓе баратели на азил често се стремат да добијат статус на бегалци, напуштајќи ја сопствената држава и барајќи меѓународна заштита. Сепак, доколку се процени дека тие немаат потреба од заштита, можат да бидат вратени во матичните држави. За разлика од бегалците кои од егзистенционален аспект се принудени да ја напуштат сопствената држава, мигрантите ги сочинуваат и луѓе кои напуштањето на сопствените држави нужно не го поврзуваат со државни или егзистенцијални притисоци и прогони. Притоа, мигрантот продолжува да биде под заштита на својата матична држава дури и кога е во странство. Тоа најдобро го потврдува примерот со економските, образовните, културните и слични мигранти. Исто така, за разлика од бегалците чие враќње во матичните држави е ризично од безбедносен аспект, мигрантите не се соочуваат со таков предизвик.

Правењето разлика помеѓу бегалец и мигрант е неопходно од неколку аспекти. Имено, справувањето со миграциските предизвици начелно се базира на националните законодавства и процедури, додека справувањето со бегалците се базира врз националните и меѓународните норми за нивна заштита. Во овој контекст, државите се соочуваат со специфични одговорности кон секое лице барател на азил на нивната територија или државна граница.

Од аспект на неопходната заштита, неприфатливо е изедначување на статусот бегалец со статусот мигрант, бидејќи тоа може да продуцира сериозни последици за животот и безбедноста на бегалците. Комбинирањето и погрешната употреба на двата термина го одвлекува вниманието од специфичната правна заштита неопходна за бегалците. Тоа, пак, може да иницира намалување на поддршката од јавноста за нив и за прашањето на азил и тоа во ситуации кога бегалците имаат итна и егзистенцијална потреба од заштита.

Во однос на актуелната криза со која се соочува ЕУ на овој план, постојат одредени предизвици во контекст на нејзиното терминолошко определување. Конкретно, најголемиот дел од луѓето кои настојуваат да се преселат или се веќе преселени на нејзина територија потекнуваат од Сирија (околу 360.000 во 2015 година) и од Авганистан (околу 170.000 во 2015 година). ${ }^{9}$ Воените дејства во Сирија и повторното актуализирање на насилството во Авганистан во целост го оправдуваат статусот на бегалщи за луѓето кои ги напуштаат овие држави. Сепак, ваквиот

\footnotetext{
${ }^{9}$ Извор: EUROSTAT
} 
статус не е потполно адекватен за сите луѓе кои користејќ ја истата рута за влез во ЕУ, пред сѐ преку Грција и Италија, пристигнуваат од Ирак, Иран, Пакистан, Косово, Албанија, Еритреја, Нигерија и државите од северниот дел на Африка. Од аспект на причините за напуштање на овие држави, тие ја претставуваат групата баратели на азил и економски мигранти.

\section{Меѓуународни аспекти на заштитата на бегалците и мигрантите}

Меѓународната заштита на бегалците и мигрантите, генерално, произлегува од универзалниот систем за заштита на човековите права во кој доминантно влијание имаат инструментите на $\mathrm{OOH}$ во оваа сфера. Универзалната декларација за човековите права на ООН претставува најзначаен инструмент за регулирање на човековите права во глобални рамки. Декларацијата го содржи т.н. прв каталог на човековите права и во тој контекст таа содржи спектар на права кои се од посебна важност за бегалците и мигрантите. Тука, особено се значајни: правото на живот, слобода и безбедност, забрана на ропство и мачење и на други облици на малтретирање, потоа забрана на дискриминација, на произволно апсење и протерување, право на правично судење, право на приватен и семеен живот, слобода на движење, право на државјанство, право на склучување брак, право на имот, слобода на вероисповед, изразување и здружување, како и политички права. Посебно значење има и член 14 бидејќи тој првпат на меѓународен план го гарантира правото на азил, т.е. правото секој да бара и да добие престој и засолниште во друга држава како резултат на разни прогонувања. ${ }^{10}$

Во 1966 година, универзалниот систем за заштита на човековите права е надополнет со две конвенции: Пакт за граѓански и политички права и Пакт за економски, социјални и културни права. Овие конвенции, исто така претставуваат значаен извор на човековите права кои ги опфаќаат и бегалците и мигрантите. Пактот за граѓански и политички права ги содржи речиси истите прокламирани права во Декларацијата, додека вниманието на вториот пакт е насочено кон обезбедување поволни услови на поединците за работа, правична награда за нивната работа, социјално обезбедување, основно образование и остварување на нивните културни потреби.

Заштитата на бегалците во рамките на посочениот универзален систем дополнително е регулирана и со одредени одредби од IV Женевска конвенција од 1949 година и Протоколот од 1977 година, како и со Конвенцијата за статусот на бегалците на ООН од 1951 година и нејзиниот протокол од 1967 година.

Конретно, co IV Женевска конвенција се забрануваат принудни преселувања, масовни или поединечни, како депортација на заштитени лица од окупирана територија на територија на друга држава, без оглед на мотивите на тие дејства. ${ }^{11}$ Оттука, според Конвенцијата, лицата кои ја напуштиле својата држава треба да имаат статус на бегалци, наместо ад хок да се третираат како странци кои се не-

${ }^{10}$ Овој член не се однесува на лицата кои имаат извршено кривично дело кое нема политичка природа или кое е спротивно на целите и начелата на Повелбата на ООН.

11 Чл. 49, IV Женевска конвенција, 1949. 
пријателски државјани само затоа што тие правно припаѓаат на некоја друга, а во одредени ситуации дури и непријателска држава.

Протоколот од 1977 година дополнително го регулира прашањето за заштитата на бегалците. Имено, според него, категорично се забранети во секое време и на секое место да се реализираат следниве акти: насилство над физичкиот и психичкиот интегритет на луѓето (убиства, мачење од секаков вид, телесни казни и сакатења), навредување на човековото достоинство и понижување (присилна проституција и секоја форма на недоличен напад), земање заложници и колективни казни, вклучувајќи ја и самата закана дека ќе биде извршен некој од посочените акти.

Конвенцијата за статусот на бегалците на ООН претставува основен документ со кој се утврдува дали некое лице ги исполнува условите за стекнување статус на бегалец и следствено на тоа за обезбедување соодветна помош и заштита. Во регулирањето на заштитата на бегалците, Конвенцијата тргнува од недискриминацијата, т.е. од обврската на државите-потписнички за доследна примена на одредбите од неа врз бегалците, без дискриминација во поглед на расата, верата или земјата на потекло. ${ }^{12}$ Конвенцијата го гарантира и правото на слободно движење, што значи дека бегалците кои континуирано се наоѓаат на територијата на одредена држава имаат право слободно да го изберат местото на живеалиштето и слободно да се движат согласно со воспоставените национални прописи кои се применуваат на странци. Исто така, предвидено е и издавање соодветни документи за идентитетот на секој бегалец кој се наоѓа надвор од матичната држава и не поседува документи кои го потврдуваат неговиот идентитет. ${ }^{13}$ Во однос на можноста за протерување на бегалците и загрозување на нивната безбедност, конвенцијата истакнува дека државите-потписнички се обврзани да не реализираат протерување на бегалците врз национална, расна, религиска, политичка или друга основа на територија каде што ќе биде загрозен нивниот живот. Сепак, ваквата одредба не се однесува на бегалците за кои постојат потврдени информации дека претставуваат безбедносна закана за државата во која се наоѓаат, како и за оние за кои е донесена конечна судска одлука за сторено кривично дело. ${ }^{14}$

Меѓународниот пристап кон прашањето за бегалците дополнително е зајакнат со воспоставувањето Канцеларија на високиот комесар на ООН за бегалци (UNHCR). ${ }^{15}$ Согласно со статутот на Канцеларијата, високиот комесар дејствува во насока на обезбедување меѓународна заштита на бегалците и во изнаоѓање трајни решенија за нив, притоа помагајќи им на владите да ја олеснат доброволната репатријација на бегалците или на нивната асимилација во новите средини. Оттука, при извршување на должноста, комесарот одржува непосреден контакт со владите, со меѓународни владини и со невладини организации кои се грижат за состојбата на бегалците. Во првата половина на 2015 година, UNHCR водеше гри-

\footnotetext{
${ }^{12}$ Чл. 3. Конвенција за статусот на бегалците, ООН,1951.

${ }^{13}$ Ibid.чл. 27

${ }^{14}$ Ibid. чл. 33

${ }^{15}$ Канцеларијата е воспоставена со Резолуција на Генералното собрание на ООН во 1949 година.
} 
жа за околу 58 милиони лица во светот. ${ }^{16}$ Генерално, станува збор за насилно раселени лица, особено бегалци, баратели на азил, внатрешно раселени лица, како и лица без државјанство. Според извештајот на UNHCR од јуни 2015 година, забележливо е зголемување на бројот на бегалците во последните четири години. Конкретно, од околу 10.4 милиони бегалци на крајот од 2011 година, следната 2012 година бројот изнесува 10.5 милиони, потоа 11.7 милиони во 2013 година, 14.4 милиони на крајот од 2014 година, додека на средината од 2015 година бројот изнесува 15.1. милиони бегалци, што претставува највисоко ниво во изминатите 20 години. Инаку, за главен контрибурачки фактор на интензивното зголемување на бројот на бегалците е идентификувана војната во Сирија. ${ }^{17}$ Покрај состојбата во Сирија, како дополнителни детерминирачки фактори извештајот ги посочува новите, како и интензивирањето на постоечките кризи и насилство во: Авганистан, Бурунди, Демократска Република Конго, Мали, Сомалија, Јужен Судан и Украина.

Од друга страна, заштитата на правата на мигрантите е регулирана со т.н. меѓународно миграционо право. Станува збор за одредени воспоставени правила во различни потсистеми на меѓународното јавно право, како што се: меѓународното право на човековите права, меѓународното хуманитарно право и меѓународното кривично право, кои се однесуваат на мигрантите. Со оглед на фактот дека мигрантите често претставуваат хетерогена група, на меѓународен план сѐ уште не постои единствен збир на норми кои директно би се однесувале на нив. Затоа и правилата на миграционото право произлегуваат од останатите потсистеми на меѓународното право, при што различни инструменти се применуваат во зависност од контекстот и конретната миграциска група: дали станува збор за бегалци, раселени лица или мигрантски работници.

Меѓународната конвенција за заштита на правата на работниците-мигранти и членовите на нивните семејства (1990) претставува единствена меѓународна конвенција која конретно се однесува на мигрантите. Останатите конвенциии кои се однесуваат на мигрантите опфаќаат само одделни делови или области од нивниот живот. Сепак, не треба да се занемари фактот дека сите конвенции од сферата на човековите права воспоставуваат правила за сите лица кои се наоѓаат на територија на една држава, вклучувајќи ги и самите мигранти. Во тој контекст, значајни се: Меѓународната конвенција за укинување на сите облици на расна дискриминација; Конвенцијата за елиминирање на сите облици на дискриминација на жените; Конвенцијата против тортура и други сурови, нечовечки или понижувачки казни и постапки; Конвенцијатра за правата на децата; Меѓународната конвенција за заштита на сите лица од принудни исчезнувања.

\footnotetext{
${ }^{16}$ Годишен извештај на UNHCR, 2015, стр.3. Текстот достапен на: http://www.unhcr.org/56701b969.html

${ }^{17}$ Ibid.
} 


\section{Предизвици и пристапот на ЕУ кон бегалско-мигрантската криза}

Интензивирањето на бегалскиот и мигрантскиот бран кон ЕУ во текот на 2015 година иницираше отворање низа дилеми за ефикасноста на начинот со кој таа се справува со оваа криза. Тоа само по себе продуцираше и одредени предизвици за ЕУ, особено во поглед на намалувањето и елиминирањето на нелегалните миграциски рути, потоа во утврдувањето ефикасен заеднички европски одговор, како и во поглед на релоцирањето и интеграцијата на веќе пристигнатите бегалци и мигранти на европска почва. Токму затоа, ЕУ се соочи со потребата од примена на еден сеопфатен стратегиски пристап кој истовремено ќе ги опфати сите аспекти на кризата, започнувајќи од причините за неа, транзитните рути и регулирањето на статусот бегалец и мигрант, прашањето за пристигнатите бегалци и мигранти, па сѐ до определувањето неопходна финансиска, хуманитарна и оперативна помош како за нејзините држави-членки кои први се соочуваат со кризата (посебно Грција и Италија), така и за Турција како главна транзитна база од која луѓето пристигнуваат на европска почва.

Во тој контектст, утврдено е дека конфликтот во Сирија претставува доминантен фактор за појавата и интензивирањето на бегалско-мигрантската кри$3 a,{ }^{18}$ додека сѐ уште присутното насилство во Авганистан и во Ирак, злоупотребите во Еритреја, како и предизвиците од економска и финансиска природа со кои се соочува Косово, исто така, се значајни детерминирачки фактори за актуелните миграции кон ЕУ.

Крајната дестинација до која настојуваат да пристигнат бегалците и мигрантите, вообичаено, се најразвиените држави во ЕУ: Германија, Шведска, Австрија. Во однос на примените барања за азил, на прво место е Германија со примени 476.000 барања во 2015 година, додека на второ место е Унгарија со примени 177.130 апликации до крајот на декември 2015 година. ${ }^{19}$ Станува збор за официјални бројки со кои не се опфатени бегалците и мигрантите кои нелегално престојуваат на територијата на овие држави. Инаку, иако Германија има примено најмногу барања за азил во 2015 година, сепак, споредено со глава на жител, и покрај тоа што ги затвори своите граници како одговор на бегалско-мигрантската криза, Унгарија е на прво место со речиси 1.800 апликации на 100.000 локално население. По неа следува Шведска со 1.667 апликации на 100.000 , додека соодносот во Германија беше 587 апликации, а за Велика Британија само 60 апликации на 100. 000 локално население. Генерално, просекот во ЕУ изнесува 260 апликации за азил на 100.000 жители на ЕУ. ${ }^{20}$ Сепак, наспроти големиот број поднесени апликации, во текот на 2015 година земјите од ЕУ имаат одобрено азил за вкупно 292. 540 лица.

\footnotetext{
${ }^{18}$ Во овој труд е употребен терминот бегалско-мигрантска криза затоа што луѓето кои мигрираат кон ЕУ претставуваат хетерогена група составена од бегалци, пред сѐ, од Сирија и од Авганистан и мигранти претежно од Африка.

${ }^{19}$ Извор: http://ec.europa.eu/eurostat/statisticsexplained/index.php/Migration_and_migrant_popu lation_statistics

${ }^{20}$ Ibid.
} 
Од аспект на пристапите до територијата на ЕУ, според Меѓународната организација за миграција, во текот на 2015 година повеќе од 1.011 .700 луѓе пристигнале по воден, т.е. морски пат, додека околу 34.900 по копнен пат. Повеќе од половината од нив ја сочинува населението на три држави: околу 350.000 од Сирија, 180.000 од Авганистан, 125.000 од Ирак. Станува збор за енормно зголемување на бројот на овие лица споредено со 2014 година, кога вкупно и по воден и по копнен пат нивниот број изнесуваше 280.000. Во првата половина на 2016 година, заклучно со 18 мај, вкупно 196.325 бегалци и мигранти имаат пристигнато на европска почва (155.975 преку Грција и 33.907 преку Италија). ${ }^{21}$

Ваквиот енормен прилив на луѓе иницираше појава и на една од најсериозните кризи во ЕУ, која практично ја доведе во прашање Даблинската уредба за правилата на барање и доделување азил, ${ }^{22}$ паралелно со тоа поделувајќи ги државите-членки и нивните лидери во однос на адекватните пристапи и начини за прифаќањето и интегрирањето на бегалците и мигрантите, како и во однос на дилемата дали воопшто треба да им се овозможи пристап на територијата на ЕУ. Тука може да се лоцира причината за бавната реакција на ЕУ во однос на оваа криза во изминатиот период.

Според унгарскиот премиер Виктор Орбан, неопходно е Унгарија да ги брани националните и европските граници заради ,зачувување на христијанската Европа“. ${ }^{23}$ Согласно со тоа, Унгарија, како главна точка на рутата за премин на бегалците и мигрантите во шенгенската зона на ЕУ, пристапи кон изградба на жичена ограда за затворање на границата и спречување нов бегалски и мигрантски бран на нејзина територија. Ваквиот одговор подоцна го применуваа и Австрија, Словенија и Македонија.

Од друга страна, особено во почетокот на кризата, германската канцеларка Ангела Меркел сметаше дека одговорот на ЕУ мора да се базира на толеранци$\mathrm{ja}$, помош и почитување на бегалците и мигрантите. Затоа, според неа, неопходно е жителите на ЕУ и особено на Германија да не се сомневаат и да веруваат дека големите и различните цивилизации можат да градат и заеднички мостови на заемно почитување и толеранција. ${ }^{24}$ Сепак, отпорот кон ваквата политика на отворени врати е зајакнат и со притисокот на Вишеградската група држави (Чешка, Словачка, Унгарија и Полска), која отоворено се спртивстави на планот за пропорционална распределба на мигрантите и бегалците во државите на ЕУ.

Колективниот, заеднички одоговор на ЕУ кон бегалско-мигрантската криза, како еден од политичките приоритети на Европската комисија, се базира на определбата за примена на еден сеопфатен пристап во нејзино решавање. Тоа е затоа што кризата се разви во една комплексна појава која не може да се третира преку

${ }^{21}$ Извор: http://www.iom.int/sites/default/files/situation_reports/file/Europe-Med-Migration-Response-Sitrep21-19May.pdf

${ }^{22}$ Уредбата е усвоена во 2002 година. Текстот е достапен на: https://www.refugeecouncil.org. uk/assets/0001/5851/dublin_aug2002.pdf

${ }^{23}$ Извор: http://www.slobodnaevropa.org/content/izazovi-pred-eu/27432007.html

${ }^{24}$ Ibid. 
еден единствен и универзален пристап. Во тој контекст, ЕУ ја препозна потребата од дефинирање итни мерки заради спречување човечки трагедии, како и за зајакнување на механизмите за справување со вонредни ситуации. За таа цел, ЕУ пристапи кон зајакнување на присуството во Средоземно Море заради помош при бродските несреќи со кои се соочуваат бегалците и мигрантите, потоа кон зголемување на бројот на легални бегалци од трети земји, како и кон користење оперативни и финансиски инструменти со цел соодветна помош на државите-членки кои први се соочуваат со бегалско-мигрантскиот бран.

Покрај тоа, на 13 мај 2015 година, ЕУ дефинираше нов стратегиски пристап за подобро справување со миграцијата на среден и на долг рок. Во тој контекст, дефинирани се неколку правци врз кои е потребно да се базира новата Европска миграциска програма. Конретно, станува збор за:

- намалување на мотивацијата за незаконска миграција, посебно преку упатување на европски службеници за миграциски прашања во делегациите на ЕУ во најважните т.н. трети земји, како и преку промени во правната регулатива на FRONTEX заради јакнење на неговата улога во одвраќањето на миграциските движења на границите на ЕУ;

- гранично управување - спасување животи и заштита на надворешните граници преку јакнење на улогата и капацитетите на FRONTEX, преку помош и јакнење на капацитетите на т.н. група држави од трет свет за управување на нивните граници;

- должноста на ЕУ за обезбедување заштита, но и јасна и недвосмислена политика за азил, преку обезбедување целосна и усогласена реализација на политиката за азил, особено во однос на процедурите за идентификација и земање отпечаток од прст, а заради намалување на злоупотребата на азилот;

- нова политика за законски миграции, тука акцентот е ставен на одржувањето на Европа која е во демографски пад, како привлечно одредиште за мигрантите, посебно преку преиспитување на приоритетите на нејзините интеграциски политики и преку зголемување на придобивките од нив како за поединците, така и за државите на нивното потекло. ${ }^{25}$

Речиси една година подоцна, т.е. на 18 март 2016 година, ЕУ иницираше уште еден стратегиски одговор во однос на актуелната бегалско-мигрантска криза. Конретно, ЕУ постигна договор ${ }^{26}$ со Турција како главна транзитна држава од која бегалците и мигрантите пристигнуваат на европска почва, за ставање крај на нелегалната миграција и за нејзина замена со легални канали на миграција со што би се обезбедило давање соодветна меѓународна заштита во согласност со меѓународното право.

Договорот се базира на девет принципи:

\footnotetext{
${ }^{25}$ Извештај на Европската комисија од 13 мај 2015. Извор: http://europa.eu/rapid/press-release_IP-15-4956_hr.htm

${ }^{26}$ Договорот стапи во сила на 20 март 2016 година и тој предвидува најдоцна до 4 април 2016 година да започне процесот на враќање на бегалщите и мигрантите кои по 20 март 2016 година од Турција пристигнале во Грција.
} 
- враќање во Турција на сите нелегални мигранти без оглед на тоа дали тие не аплицирале за азил или, пак, нивната апликација е одбиена, кои по 20 март 2016 година од Турција се пристигнати на грчките острови; ${ }^{27}$

- реципроцитет во преземањето сириски бегалци од турска територија во ЕУ со бројот на сириските бегалци кои од грчките острови ќе бидат вратени во Турција (целта е елиминирање на постоечките нелегални и опасни миграциски текови);

- преземање од страна на Турција на сите неопходни мерки за спречување нови бегалски и мигрантски бранови по воден и по копнен пат кон ЕУ;

- активирање на доброволна хуманитарна помош за Турција откако ќе биде ставен крај на нелегалните транзитни рути помеѓу неа и ЕУ или откако тие значително ќе се намалат;

- укинување на визниот режим на ЕУ за турските граѓани најдоцна до крајот на јуни 2016 година доколку Турција ги реализира договорените неопходни активности за спречување на приливот на бегалци и мигранти кон ЕУ;

- забрзување на исплатата на првично определените 3 милијарди евра на Турција за справување со бегалците; откако овие ресурси ќе бидат искористени во целост, ЕУ се обврзува да мобилизира и дополнителни, најмногу 3 милијарди евра за помош на Турција до крајот на 2018 година;

- унапредување на соработката помеѓу ЕУ и Турција во однос на царинската унија;

- активирање на процесот за членство на Турција во ЕУ преку отворање на прашањата од поглавјето 33 во текот на холандското претседателство со Советот на ЕУ; и

- заедничко дејствување на ЕУ и Турција во однос на подобрување на хуманитарните услови во Сирија. ${ }^{28}$

Во насока на ефикасна имплементација на Договорот, Грција, исто така, беше задолжена да преземе одредени активности:

- дислокација на нејзино копно на сите бегалци и мигранти пристигнати на островите пред 20 март;

- враќање во Турција на 147 илегални мигранти за кои е утврдено дека не подлежат на меѓународна заштита и кои во Грција се пристигнати пред 20 март;

- испраќање и распоредување на нејзини офицери за врски во Турција;

- распоредување на островите на 1.500 офицери за азил и полициски службеници;

- трансформирање на т.н. жаришта на нејзината територија во прифатни центри од затворен карактер со цел да се елиминира можноста за бегство на мигрантите кога тие ќе бидат предмет на одлука за враќање назад, посебно во Турција. ${ }^{29}$

\footnotetext{
${ }^{27}$ На првиот ден од имплементацијата на Договорот, врз основа на член 1, 32 сириски бегалци се преземени во Германија, а 11 во Финска.

${ }^{28}$ Извештај на Европска комисија, 4 април 2016 година. Извор: http://europa.eu/rapid/pressrelease_MEMO-16-1221_en.htm

${ }^{29}$ Ibid.
} 
Од друга страна, Турција, исто така, се обврза на исполнување на следниве активности:

- распоредување на офицери за врска во Грција;

- повторно разгледување на оправданоста на заштитниот статус на сите сириски бегалци кои од грчките острови ќе бидат вратени во Турција; за таа цел, реализирање и на соодветни промени на националното законодавство; и

- гарантирање дека сите луѓе кои ќе бидат вратени од Грција, а кои имаат потреба од меѓународна заштита ќе имаат пристап до процедурите за азил на турска територија. ${ }^{30}$

Постигнатиот договор помеѓу ЕУ и Турција уште на почетокот иницираше одредено намалување на интензитетот на бегалско-мигрантскиот бран. Имено, бројката од 1.667 бегалци и мигранти пристигнати во Грција на 20 март речиси две недели подоцна, т.е. на 3 април е намалена на 339. ${ }^{31}$ Сепак, ова е само еден од повеќето аспекти кои ЕУ ги дефинираше за справување со бегалско-мигрантската криза. Покрај тоа, сѐ уште останува отворено прашањето за бегалците и мигрантите кои се наоѓaат на грчка територија, што имплицира бавна реализација на член 1 од Договорот помеѓу ЕУ и Турција. Тука, проблемот, меѓу другото, произлегува од фактот дека не го прифаќаат сите ЕУ-држави, посебно Велика Британија и Ирска, принципот за реципрочно распоредување на нивна територија на бегалците кои ке бидат испратени од Турција. Со ваквиот пристап, Грција и понатаму останува да биде прва држава-членка на ЕУ која директно е соочена со сите предизвици поврзани со бегалско-мигрантската криза. Покрај тоа, во насока на елиминирање на причините за кризата, несомнено е дека е потребен и еден брз, сеопфатен и координиран пристап на ЕУ и Турција во контекст на безбедносната стабилизација и постконфликтното градење на мирот во Сирија. Сепак, од аспект на потребната временска дистанца за ефикасно постигнување на претходно посоченото, останува отворена дилемата дали до крајот на 2016 година ЕУ ќе успее ефикасно да ги реши сите аспекти на актуелната бегалско-мигрантска криза.

\section{Заклучок}

Интензивирањето на бегалскиот и мигрантскиот бран кон ЕУ во текот на 2015 година иницираше повеќе сериозни предизвици посебно во поглед на нејзината институционална и оперативна функционалност. Покрај тоа, кризата иницираше и сериозни дилеми и внатрешни поделби помеѓу државите-членки, како во поглед на интеграцискиот пристап кон веќе пристигнатите бегалци и мигранти, така и кон неопходните инструменти за затворање на активните транзитни рути и за спречувањето нови масовни преселувања и барања азил на територијата на ЕУ. Токму поради тоа, во почетокот на кризата EУ не манифестираше брз, јасен и ефикасен одговор. Напротив, тој, главно, се базираше на националните активности и мерки на државите-членки кои се движеа од политика на отворени врати (пристап на германската канцеларка Ангела Меркел), па сѐ до затворање граници

\footnotetext{
${ }^{30}$ Ibid.

${ }^{31}$ Ibid.
} 
и изградба на жичени блокади за нивна заштита (пристапот на Унгарија, кој потоа го применуваат и балканските држави). Со оглед на фактот дека ниту еден од посочените пристапи не успеа да ја елиминира кризата или да го намали нејзиниот интензтитет, во март 2016 година ЕУ, кончено, презентираше еден конкретен и повеќедимензионален одговор. Станува збор за постигнатиот договор со Турција како почетна и главна транзитна база за најголем број бегалци и мигранти, чијашто реализација треба да обезбеди ефикасно решавање на кризата. Договорот е значаен од повеќе аспекти: определбата на ЕУ за давање соодветна заштита во согласност со меѓународните правни норми на бегалците; правењето дистинкција помеѓу луѓето со статус бегалец и статус мигрант; определбата за истовремено дејствување во насока на затворање на мигрантските рути, интеграцијата на пристигнатите бегалци, враќањето на оние кои не подлежат на заштита согласно со принципите на статусот бегалец и мигрант или кои претставуваат безбедносен ризик; дислокација на бегалците и мигрантите од Грција во Турција и спречување нов бран бегалци и мигранти уште на турска почва. Паралелно со тоа, а во насока на елиминирање на причините за кризата, ЕУ и Турција се обврзаа на заеднички пристап во безбедносната стабилизација и постконфликтното градење на мирот во Сирија. На овој начин, ЕУ манифестираше одлучност за сериозен одоговор на најсериозната криза со која се соочи во изминатиот 25-годишен период. Сепак, нејзиното успешно решавање ќе биде директно детерминирано од целосното исполнување на сите определби од посочениот договор. 


\section{Литература}

Bennett, A.L., Oliver, K.J. (2001). International Organizations: Principles and Issues, Pearson Publishing, Cambridge.

Castles, S., Miller, M. (2003). The Age of Migration: International Population Movements in the Modern World, The Guilford Press, New York.

Caldwell, C. (2009). Reflection on the Revolution in Europe: Immigration, Islam, and the West, Doubleday, New York.

Годишен извештај на UNHCR, 2015 (достапен на: http://www.unhcr.org/56701b969 $. h t m l)$.

Извештај на Европската комисија од 13.5.2015 (достапен на: http://europa.eu/rapid/ press-release_IP-15-4956_hr.htm).

Извештај на Европската комисија од 4.4.2016 (достапен на: http://europa.eu/rapid/ press-release_MEMO-16-1221_en.htm).

Извештај на Меѓународната организација за миграции од 19-21.5.2015 (достапен на: Извор: http://www.iom.int/sites/default/files/situation_reports/file/EuropeMed-Migration-Response-Sitrep21-19May.pdf).

Извештај на EUROSTAT за бегалците и мигрантите во Европа во 2015 година (достапен на:http://ec.europa.eu/eurostat/statisticsexplained/index.php/Migration_and_migrant_population_statistics).

Конвенција за статусот на бегалците, ООН, 1951 година (достапна на: http://www. unhcr.org/about-us/background/4ec262df9/1951-convention-relating-statusrefugees-its-1967-protocol.html)

Koser, K. (2007). International Migration: A Very Short Introduction, Oxford University Press, USA.

Универзална декларација за човековите права, ООН, 1948 година (достапна на: http://www.ohchr.org/EN/UDHR/Documents/UDHR_Translations/eng.pdf). 
Nikolcho SPASOV

Aleksandar PAVLESKI

\section{THE EUROPEAN UNION AND THE REFUGEE-MIGRATION CRISIS: CHALLENGES AND RESPONSE}

\section{Summary}

An intensification of refugee and migrant wave to the EU has initiated a more serious challenges especially in terms of its institutional and operational functionality. In addition, the crisis initiated serious dilemmas and internal divisions among Member States, both in terms of the integration approach to the refugees and migrants that have already arrived in EU as well as to the needed instruments related to closing the active transit routes and the prevention of a new mass migrations and requirements asylum. Therefore, the EU has not manifested fast, clear and effective response at the beginning of the crisis. However, the signing of the Agreement with the Turkey (March, 2016), has marked the beginning of a more serious EU approach in dealing with the crisis. The Agreement is significant because it presents a comprehensive approach in solving of the refugee and migrant crisis through the inclusion of more players, as well as through simultaneous action in reducing and eliminating the crisis causes and consequences. Still, in term of the required time for effective implementation of the Agreement, it remains open dilemma if the EU will be able for effectively solving of all crisis aspects by the end of the 2016.

Keywords: EU, REFUGEES, MIGRANTS, CRISIS 